Vol. 6, No. 1, 2019

https://doi.org/10.23939/eem2019.01.001

UDC 338.4:[658:005.5]

JEL Classification Code M1, 03

\author{
O. Kuzmin \\ Lviv Polytechnic National University, Ukraine, Doctor of Economics, Professor \\ E-mail: Oleh.Y.Kuzmin @lpnu.ua \\ ORCID: 0000-0002-6014-6437
}

V. Ovcharuk

Lviv Polytechnic National University, Doctor of Economics, Associate Professor

E-mail: Vadym.V.Ovcharuk@lpnu.ua

ORCID: 0000-0002-6176-304X

V. Zhezhukha

Lviv Polytechnic National University, Ukraine, PhD, Associate Professor

E-mail: Volodymyr.Y.Zhezhukha@1pnu.ua

ORCID: 0000-0003-0962-8366

\title{
ECONOMIC EVALUATION OF ADMINISTRATION SYSTEMS IN THE CONTEXT OF MANAGEMENT BUSINESS PROCESSES REENGINEERING
}

\begin{abstract}
The article deals with the peculiarities of an economic evaluation of administrative systems in the context of management business processes reengineering. In particular, methodological approaches to the economic evaluation of such systems are described and characterized. It is concluded that under present conditions most of the projects on construction or improvement of administrative systems belong to the category of investment projects, which, accordingly, are related to investment costs. Consequently, this necessitates the implementation of commonly used in investment management methodical approaches for the economic evaluation of the investments' efficiency in the administration systems. The main approaches to the economic evaluation of administrative systems in the frameworks of management business processes reengineering are outlined and characterized. They include traditional financial methods, probabilistic methods, qualitative analysis tools, financial, qualitative or combined models, portfolio analysis, budget approach, project approach. Thus, the traditional financial methods of the economic evaluation of the administration systems in the management of enterprises
\end{abstract}

provide for the calculation of the payback period, the net present value, the internal or average rate of return, the profitability index, the level of investments' return, etc. Among the methods and approaches to solving the problem, the estimated Total Cost of Ownership (TCO), IT Scorecard (consideration of customer projections, finance, processes and training and development in the frameworks of administrative processes in the enterprise and administration systems) on enterprise and administration systems), Activity Based Costing (ABC), Cost/Schedule Control Systems Criteria (C/SCSC), Applied Information Economics (AIE), Total Value of Opportunities (TVO), Total Economic Impact (TEI), Rapid Economic Justification (REJ), etc. The hypothesis about the influence of administrative systems on the resulting indicators of a business entity was confirmed based on the results of calculations. This problem has been solved using correlation-regression analysis. Net income from sales of products (which is known to be one of the most representative absolute indicators of the economic efficiency of production and economic activity of the enterprise) was selected as the resulting (or dependent) variable. Among the independent 
variables (factor characteristics), the indicators of the level of administrative systems formation $\left(\mathrm{R}_{\mathrm{sfr}}\right)$ and the level of their stability $\left(\mathrm{R}_{\text {stk }}\right)$ were chosen to solve the problem. Appropriate calculations to verify the hypothesis were done for the activities of a number of domestic business entities.

Key words: administration, business process, economic evaluation, reengineering, system, management.

\section{Introduction}

In modern companies, considerable attention is given to the problems of formation, use and economic evaluation of administration systems in management in the conditions of transition to new management standards, as well as in the frameworks of management business processes reengineering. Under these circumstances, managers do not restrict their interest in the problems of such systems after the successful implementation of new management standards, realizing that the administration system is the key to competitive advantages in a dynamic operating environment. Often, the need to rebuild such systems is due both to customer requirements and to a significant gap in this direction between customers and their competitors (that enables to identify, in particular, benchmarking). It often happens in business that the decision to improve the administration system is conditioned by the need to implement a quality management system and its requirements regarding the completeness, timeliness, efficiency and focus of information and document security during the influence of the management system on the control of all management technology stages. One way or another, any system of administration in modern companies is characterized by dynamism and requires constant monitoring of its state and trends, first of all, from the position of the economic component. This is especially true in the context of enterprises' management business processes reengineering.

\section{Literature review and methodical approaches}

Different levels of administration, construction and economic evaluation of corresponding systems are considered in works of O. Avdieieva, I. Adizes, I. Alieksieiev, N. Bakanova, L. Batchenko, O. Bezborodova, M. Biesiedin, M. Bondarchuk, I. Borysenko, M. Bublyk, I. Vishka, M. Voinarenko,
Yu. Volohin, N. Havkalova, P. Hlushchenko, S. Honhalo, S. Davymuka, B. Dosmukhamedov, I. Drahan, O. Dudchenko, N. Epifanova, O. Zamazii, H. Zakharchyn, H. Kaihorodtsev, T. Kamenska, Z. Kvi, A. Kisielov, N. Kvak, V. Klochkov, O. Koval, A. Kovalchuk, O. Kostiuk, T. Kravtsova, A. Kravchenko, A. Krasnobelmova, V. Kruhlov, O. Kuzmin, V. Kulba, A. Kuprin, I. Kurshatova, O. Lazor, S. Liebiediev, K. Li, L. Lihonenko, L. Lipych, I. Litvinova, Yu. Mazneva, T. Maknalti, A. Mandrykin, L. Marshavina, Yu. Myronenko, S. Mosondz, V. Nahaiev, H. Okhrimenko, M. Petrychko, Y. Petrovych, M. Pleshakova-Borovynska, O. Podoliakin, K. Poelman, Ye. Sakhno, T. Svitlychna, T. Semenchuk, I. Skvortsov, O. Sierov, A. Solonar, Yu. Taraskina, V. Tymtsunyk, A. Uhriumova, L. Usachenko, L. Fionova, M. Chynchyn, I. Yakovliev, I. Yaremko and others. The works of these authors relates, in particular, to the strategic and tactical aspects of administration in organizations, its connection with business processes, the impact of administration on the processes of management decisions making, approaches to assessing the effectiveness of the construction and use of administrative systems, the design of these systems, the highlighting and characterizing of their elements, motivation of employees in the sphere of administrative activity, etc.

Despite a considerable number of developments in this area, a number of urgent tasks on this topic are still not resolved. Thus, the economic aspects of the evaluation of administrative systems in the frameworks of the management business processes reengineering are considered fragmentary only. Therefore, the purpose of the article is to outline the main provisions of such evaluation, the consideration of the relevant methodological provisions and the identification of the impact of administrative systems on the enterprises' economic activity indicators.

Different methods of scientific research were used to achieve the set goal and to solve the tasks: grouping and systematization methods - to distinguish methodological approaches to the economic evaluation of administrative systems; correlation-regression analysis - to identify the impact of these systems on the economic activity indicators of the enterprise; the method of expert assessments - to identify the level of stability and formation of administrative systems at enterprises. 


\section{General Provisions for the Economic}

\section{Assessment of Administration Systems}

In the realities of domestic business, the formation and use of full-fledged administration systems in its content to a greater extent belongs to the category of investment projects, which are associated with investment costs. Consequently, this necessitates the implementation of commonly used in investment management methodical approaches for the economic evaluation of the investments' efficiency in the administration systems at the management of enterprises. It is known that the ratio of investment costs and outcomes is a base for these approaches. A wide range of evaluation methods in investment management provides with an opportunity to distinguish between alternative options for investment decisions, including construction, development or improvement of administrative systems issues.

For practical reasons, the choice of any approach to the economic evaluation of investment projects for the formation and development of administration systems in the management of enterprises is determined by various factors, in particular, the time constraints of the calculations, the level of their accuracy, the level of information support on costs and cash income of the project, etc. Among other conditions influencing such evaluation processes, it is worth noting:

- level of personnel qualification in the field of investment projects evaluation;

- goals and objectives of the assessment, which, in particular, are determined by the requirements of investors, and also related to the type of the enterprise's activity and the specificity of its investment projects for the formation or development of administrative systems;

- the state of the economy, in particular, in the context of existing and potential inflation processes, etc.

Considering the problem of the economic evaluation of administrative systems in the context of management business processes reengineering, it is appropriate to agree with G. Kajgorodcev and A. Kravchenko (2015, p. 5) that the economic efficiency of information systems is significantly lower than in the case of other innovative solutions in the sphere of production. Authors explain this by the nature of information processes, which are characterized by their fundamental content.

Despite the importance and necessity of administering systems for domestic business in the present, it is nevertheless necessary to point out the considerable cost of implementation of most projects, their formation or improvement, especially when it comes to the application of modern information technologies in such systems. To this end, economic entities are compelled to accumulate financial, material, personnel and other types of resources, while taking into account a variety of possible risks. Obviously, under these conditions, a thorough economic evaluation of the project decisions' effectiveness should be carried out. This can be a prerequisite not only for risks minimization but also for carrying out economically reasonable current or capital costs. The problem is exacerbated by the implementation of large volumes of corporate information systems in the management of enterprises with complex architecture.

It should be noted that the economic substantiation of projects for the formation or improvement of administrative systems in the context of reengineering management business processes is more actualized in the context of the implementation of such projects with high budget, and provided that financial resources are planned separately for their implementation (which, as practice shows, often displayed even on a separate company budget). Under these conditions, it is important not only to plan the necessary expenses but also to work on them with the entities responsible for the company, as well as to agree on the planned budget according to the general budget of the entity.

On the basis of the scientific research results of A. Anisiforov and L. Anisiforova (2014, p. 14-15), the main preconditions to the effectiveness of economic evaluation of administration systems in the context of management business processes reengineering were distinguished, namely:

- the need to determine the real usefulness of introducing or improving administrative systems received by the enterprise or other interested entities (contractors, investors, owners, etc.);

- the need to choose such an alternative variant of IT solutions in administration systems, which will provide the opportunity to obtain the 


\section{O. Kuzmin, V. Ovcharuk, V. Zhezhukha}

most beneficial effects with the minimum cost of various resources;

- the need to outline staffing, financial, time and other constraints to achieve the expected economic and other effects;

- the need to determine the level of compliance of the expected effects to desired and the level of compliance with the established restrictions for each alternative version of the administration system in the enterprise.

It is important for the economic evaluation of the administration systems in the context of management business processes reengineering to identify significant types of all costs and benefits that most represent the economic component in the processes of implementation or improvement of these systems. In the analyzed context, it is important to use an adequate mechanism for economic diagnosis of administration systems and to apply (when it is possible) software for automating calculations.

The specifics of the economic evaluation of the administration systems in the context of management business processes reengineering is that these systems primarily aim at increasing the level of effectiveness of the management subsystem on the control one at all stages of management technology on the basis of information, documentation, case management and formalization of management procedures. Therefore, the administration system should provide the possibility of generating reliable and operational information that will be used at various levels of the organizational governance structure (since management decisions are made here, and not only at the institutional level). Thus, the costs and benefits of an economic nature associated with the construction, use or improvement of these systems; they directly or indirectly penetrate all levels of the organizational structure of management. It should be noted that the classical approaches to the economic evaluation of administrative systems involve the definition of the revenue and expenditure parts of the projects concerned, followed by their comparison in the form of absolute or relative values.

\section{Methodological approaches to the economic evaluation of administration systems \\ Considering the problem of the economic evaluation of administration systems in the}

frameworks of management business processes reengineering, one should agree with the opinion of N. Glushak (2008, p. 85), which distinguishes between two important parameters for assessing the effectiveness of information technology. The first one is the answer to the question: "what amount of consumers is satisfied with the information system and how much it costs to the organization". Another aspect is "to what extent the consumer uses his information". In this context, the author proposes to take into account two aspects of the evaluation of the effectiveness of administrative decisions on information systems, which are also typical for administration systems. The first of these efficiency aspects is the target aspect that reflects the level of the goals achievement of the enterprise (how much the administration system with all its parameters provides with the ability to make adequate the goals of the enterprise according to the requirements of the environment or, e.g. choose the most appropriate strategies for the organization that would also meet the set goals). The cost-effective aspect of evaluating the effectiveness of administrative systems is based on the criterion of minimizing costs, taking into account the relationship "volume - quality".

In the light of the foregoing, it is worth pointing out that for practical considerations during the economic evaluation of administration systems in the context of management business processes reengineering, it is important to calculate both overall and comparative efficiency for more complete information.

Taking into account the results of the research of M. Bekker (2010, p. 5), it should be noted that the economic evaluation of administrative systems in the context of reengineering management business processes can be carried out using the following main approaches:

- traditional financial techniques;

- probabilistic methods;

- qualitative analysis tools;

- financial, qualitative or combined models;

- portfolio analysis;

- budgetary approach;

- the project approach.

Considering some of these techniques that can be applied to the economic evaluation of 
administration systems in the management of enterprises, first of all, it should be highlighted the method used to calculate the minimum of costs, which was determined by the formula (Anisiforov and Anisiforova, 2014, p. 19):

$$
K_{i} \times E_{n}+C_{i} \rightarrow \min
$$

where $K_{i}$ is a volume of capital investments for each option of construction or improvement of the administration system, monetary units; $E_{n}$ is a normative coefficient of capital investments' efficiency for each option of construction or improvement of the administration system, unit fractions; $C_{i}$ is a cost price of each option for the construction or improvement of the administration system, monetary units.

Obviously, this approach can indeed be applied to the economic evaluation of administration systems in the context of management business processes reengineering, provided that such capital cost systems are formed or improved, and if it is necessary to compare at least two variants of alternative projects.

Considering the traditional financial methods of the economic evaluation of administration systems in the management of enterprises, it should be noted that they are the ones used to diagnose any investment project and are most often reflected in the investment analysis. The most common among them to solve this problem can be (Anisiforov and Anisiforova, 2014; Zamlynskyi, 2014; Skvortsov, 2003; Shemaiev and Romodan, 2014; Yastremska, 2004):

- payback period;

- net present value;

- internal rate of return;

- the average rate of return;

- modified internal rate of return;

- profitability index;

- the level of investment return, etc.

As it is known, due to the calculation of the payback period, information can be obtained when an investment project for the formation or improvement of the administration system will bring profit to the enterprise. This is one of the most common indicators to project design assessment in investment analysis. The basic formula for calculating its value provided that the cash income is uniformly distributed over the years is (Komarova, 2014, p. 61):

$$
P_{p}=\frac{I_{z}}{N_{s}}
$$

where $P_{p}$ is a payback period of the investment project on the formation or improvement of the administration system, years; $I_{z}$ is a total value of investments into the implementation of the project for the formation or improvement of the administration system, monetary units; $N_{S}$ is an average annual cash income based on the results of the formation or improvement of the administration system, monetary units.

Given the irregularity of cash incomes according to the results of formation or improvement of the administration system over the years, the payback period "will equal the period of time (the number of years) for which total net cash inflows will exceed the amount of investment" (Komarova, 2014, p. 62).

Considering the possibility of the practical application of the indicator of the administration system formation or improvement investment project payback period, it should be emphasized the need to clearly identify the average annual revenues from the system or administrative systems (which in practice is rather difficult or sometimes impossible at all). There is also a significant lack of practical application of this indicator -a disregard for the cost of money in time, which is especially important for complex and long-term projects for the formation or improvement of administration systems.

It is possible to carry out an economic evaluation of the administration systems in the management of enterprises by calculating the Net Present Value, which is to indicate the "ultimate absolute effect received from the implementation of an investment decision, and is defined as the difference between the total value of the reduced (discounted) net cash flows during the period of investment decision operation and the total value of reduced (discounted) investment funds for its realization" (Morshcheniuk, 2009, p. 110), i.e.:

$$
N P V=P V-I_{0},
$$

where $N P V$ is an amount of the net present value of the investment project for the formation or 
improvement of the administration system, monetary units; $I_{0}$ is a total cost of investments in the implementation of the project for the formation or improvement of the administration system in the zero period, monetary units; $P V$ is a value of the current cost of income from an investment project for the formation or improvement of the administration system, monetary units.

The current cost of revenue $(P V)$ from an investment project for the administration system formation or improvement is calculated as follows (Yankovyi, Melnyk and Yankovyi, 2013, p. 51):

$$
P V=\sum_{t=0}^{n} \frac{N_{t}}{(1+r)^{t}}
$$

where $N_{t}$ is a cash income based on the results of the administration system formation or improvement in the period $t$, monetary units; $r$ is a discount rate, unit fractions; $n$ is a number of periods.

Thus, the calculation of the net present value of the investment project for the administration system formation or improvement involves determining the total cost of the investment in the project implementation in the zero period (in other words, there should be determined the amount of investment obtained for the relevant project implementation). Then the current value of the proceeds from an investment project for the administration system formation or improvement is calculated. Therefore, the cash flow received for this purpose is discounted to the current date. At the final stage, the amount of such a revenue current value is compared to the total cost of investments in the project implementation for the administration system formation or improvement in the zero period.

Indicator of the payback internal rate of the investment project for the administration system formation or improvement in the management of enterprises is calculated as "discount rate, according to which the net present value of cash flow from the investment project is zero - if the calculated rate is higher than the loan interest rate or the standard refinancing rate, the project is considered to be profitable" (Anisiforov and Anisiforova, 2014, p. 29). The same authors note that the modified internal return rate is "the discount rate, which balances the project revenues and expenses; it is the rate at which the terminal value (future value of all cash inflows) will be reduced to the present moment and will be equal to the real value of all project costs (outflows)" (2014, p. 30). The formulas for calculating these indicators are (Gavrilenko, 2013; Zamlynskyi, 2014; Komarova, 2014; Morshcheniuk, 2009; Skvortsov, 2003):

$$
\begin{gathered}
N P V_{i r r}=\sum_{t=1}^{n} \frac{N_{t}}{(1+I R R)^{t}}- \\
-\sum_{t=0}^{n} \frac{I_{t}}{(1+I R R)^{t}}=0,
\end{gathered}
$$

where $N_{t}$ is a cash income based on the results of the administration system formation or improvement in the period $t$, monetary units; IRR is an interest rate at which $N P V=0 ; I_{t}$ is a volume of investments in the administration system formation or improvement (expenses) in the $t$-period; $n$ is a total number of periods (intervals, steps, etc.)

$$
\sum_{t=0}^{n} \frac{I_{t}}{(1+r)^{t}}=\frac{\sum_{i=1}^{n} N_{t} \times(1+d)^{n-t}}{(1+M I R R)^{n}}
$$

where $d$ is a level of reinvestments, unit fractions; $M I R R$ is a modified internal return rate; $r$ is a discount rate, unit fractions.

The economic evaluation of administration systems in enterprise management taking into account the European integration processes can be implemented using the profitability index (PI), which in its content shows the ratio of the present value of the future cash flow to the initial investment in the project for the formation or improvement of administration systems. Thus, this indicator shows the level of profit received for each expenditure unit (Komarova, 2014; Morshcheniuk, 2009; Skvortsov, 2003):

$$
P I=\frac{N P V}{I_{0}} .
$$

Taking into account the research results of A. Anisiforov and L. Anisiforova (2014, pp. 39-77), other methods of the economic evaluation of administration systems in the context of management business processes reengineering can be distinguished, namely:

- Total Cost of Ownership (TCO);

- IT Scorecard (consideration of customer projections, finance, processes and training and 
development in the frameworks of administrative processes in the enterprise and administration systems);

- Activity Based Costing (ABC);

- research on Cost/Schedule Control Systems Criteria (C/SCSC);

- method of Applied Information Economics (AIE);

- defining Total Value of Opportunities (TVO);

- defining Total Economic Impact (TEI);

- method of Rapid Economic Justification (REJ), etc.

Among the mentioned above methods and approaches to the economic evaluation of administration systems in the management of enterprises, it is appropriate to separately emphasize on the significant strengths of the Total Cost of Ownership (TCO). As P. Gontard, L. Stankevich, O. Gerasimova and V. Hlamov (2015, p. 89) note, TCO should be interpreted as "an innovative concept aimed at creating an understanding of the real value of conducting business with a specific supplier relative and a particular product or service". Regarding the administration system, the concept of aggregate cost of ownership involves the calculation of all direct and indirect costs that arise at any stage of the construction and use of such a system during its period of operation (for example, component purchase, installation, transportation, debugging, testing, information support, technical support, upgrade, integration, etc.).

Taking into account the key provisions of the approach from the standpoint of the total cost of ownership, it should be noted that the administration system involves two expenditure groups: direct (or budget) and indirect (hidden or extrabudgetary); during the period of use of these systems extrabudgetary costs still take a significantly larger share in the aggregate cost of ownership, so managers should identify, track, diagnose and predict it.

In the analyzed context the total cost of ownership is an excellent tool for thoroughly analyzing all possible costs associated with the construction and use of administration systems in the management of enterprises. On the other hand, it requires the identification of each part of both direct and indirect costs (for example, the cost of purchasing equipment, software, outsourcing, salaries of specialists, system design and implementation, etc.). Due to TCO, experts and analysts have the opportunity to reasonably compare the costs associated with administration systems with the results obtained. Also, if necessary, it is possible to find the most economically advisable areas for reducing the cost of a general project of the administration system construction or improvement.

An economic assessment of the administration systems in the management of enterprises from the point of view of the Total Economic Impact (TEI), for example, will cover both financial and nonfinancial aspects of the formation, use and improvement of these systems (Fig. 1).

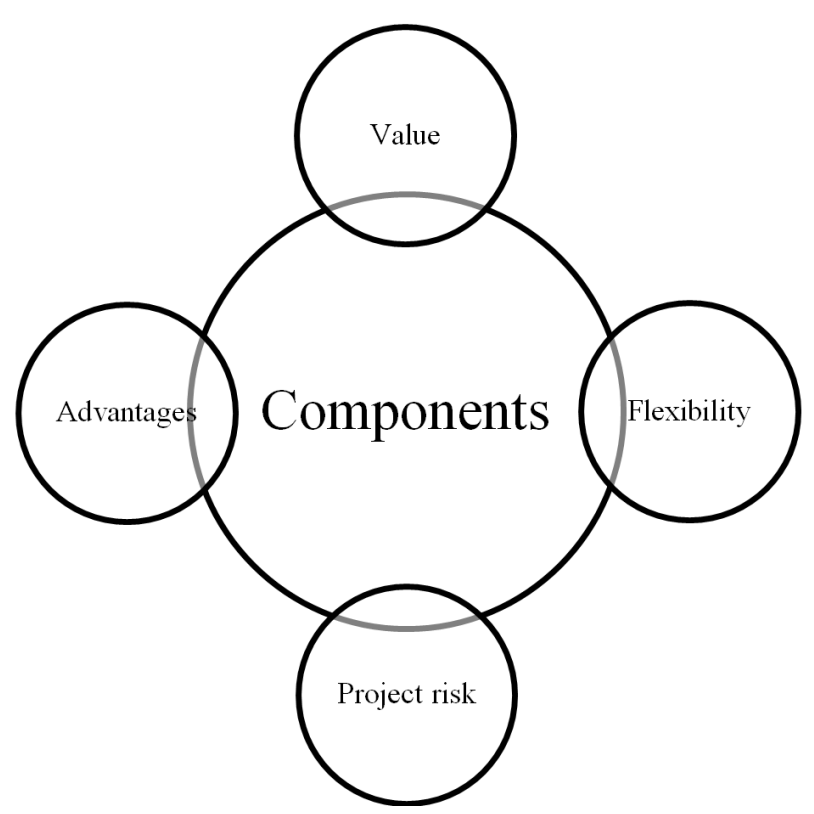

Fig. 1. Basic components of the economic evaluation of administration systems in the management of enterprises taking into account TEI

Note: formed according to Anisiforov and Anisiforova, Filippov and Shul'djasheva (Anisiforov and Anisiforova, 2014, p. 80; Filippov and Shul'djasheva, 2015, p. 57-62)

In particular, the unit "value" in the concept is calculated using the method of the total cost of ownership, therefore, involves obtaining accurate valuations. The "advantages" and "flexibility" blocks, instead, apply a number of qualitative assessments in addition to the values mentioned. 


\section{O. Kuzmin, V. Ovcharuk, V. Zhezhukha}

As V. Filippov and O. Shul'djasheva (2015, p. 61) point out, the risk as a component of the TEI model "serves as a filter, which gathers various uncertainties in assessing the benefits received". Obviously, such risks can occur at any stage of the formation, use or improvement of administrative systems in the context of management business processes reengineering.
A certain combination of different techniques for evaluating administration systems in enterprise management can be traced within the Rapid Economic Justification (REJ) method. Taking into account the results of the research N. Levkina (2009, p. 24), the REJ method involves the implementation of a series of successive stages (Fig. 2).

\section{Stage 1}

Business analysis (linking the company's goals and the goals and key indicators of a project on construction or improvement an administration system) (often by using the BCG method)



Solutions analysis (the choice of an alternative management solution based on the criterion of "necessary capabilities") (often by taking into account the criterion of "advantage" method of TEI economic effect)



Fig. 2. Stages of applying the REJ method to projects for the administration systems formation or improvement in the management of enterprises

Note: formed according to Levkina (Levkina, 2009, p. 24) 
Despite its name, this method can be considered one of the most difficult during the diagnosis of administrative systems from the standpoint of the economic component. At the same time, he is known to be an excellent combination of the administrative activity subjects' interests and managers of different levels, first of all, from the point of view of finding and identifying common interests in the construction and improvement of these systems. Thus, the basic idea behind the REJ method is to identify the relationship between costs (for example, costs for the administration system development) and the company's business priorities at a specific point in time.
One of the modern techniques that can be applied to the administration systems economic evaluation in enterprise management is the Total Value of Opportunities (TVO) methodology. This approach, unlike many others, shifts the emphasis towards reflecting the economic results of the formation or improvement of these systems. As it is noted by A. Anisiforov and L. Anisiforova (2014, p. 77), the advantage of this technique is the high level of flexibility, which allows to "adapt it to different management levels in the organization and to the relative importance of financial and nonfinancial factors". The authors singled out 5 particular directions analyzed within the TVO model (Fig. 3).

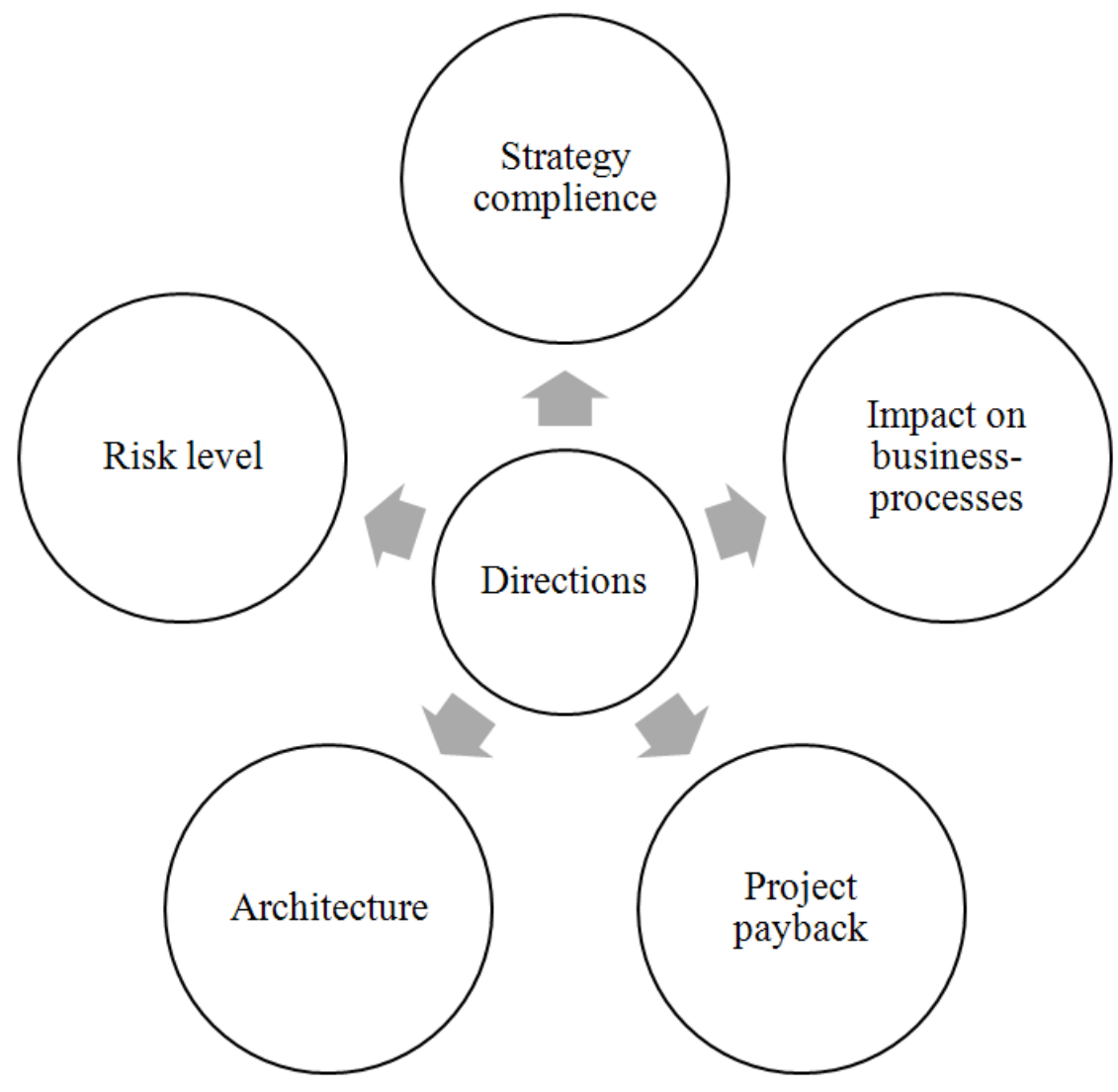

Fig. 3. Definitive directions of the economic evaluation of administrative systems in the management of enterprises within the TVO model

Note: formed according to Anisiforov and Anisiforova (Anisiforov and Anisiforova, 2014, p. 77-78)

Therefore, a project on the administration system formation or improvement in the context of management business processes reengineering from the standpoint of the methodology of calculating the aggregate opportunities value can be considered effective if it:

- contributes to the organization's strategic goals achievement (direction "strategy compliance"); 


\section{O. Kuzmin, V. Ovcharuk, V. Zhezhukha}

- positively affects the effectiveness and efficiency of a company's business processes (the direction "impact on business processes");

- corresponds to the existing information and documentary environment in the organization (direction "architecture") (the need to provide a certain level of hardware and software compliances of project decisions);

- indicates the cost-effectiveness of the project's implementation (direction "project payback");

- is within the acceptable level of risk (direction "risk level").

The study of theory and practice makes it possible to conclude that approaches to the economic evaluation of administrative systems in the context of management business processes reengineering vary greatly depending on the scale of the relevant projects. For example, in one case, such a project may involve the introduction of an internal information network in the company, and in the other, it may be needed a complete replacement of computer, switching, network and other technical equipment and the introduction of applicable software, personnel training, etc.

\section{Influence of administrative systems on economic indicators of enterprises' activity}

Practical experience shows that quite often the administration system is being implemented, developed and improved for economic reasons: to help increase income and profits, optimize costs, mobilize internal reserves, etc. In the analyzed context, the hypothesis about the influence of such systems on the resulting indicators of a business entity was provided. This problem was solved using correlation-regression analysis, which is one of the most common approaches in economic science to solving similar problems. Net income from sales of products (which is known to be one of the most representative absolute indicators of the economic efficiency of enterprise's production and economic activity) was chosen as the resulting (dependent) variable. In addition, this indicator the most fully illustrates the effectiveness of management decisions made by a business entity (implemented using administrative systems).

Among the independent variables (factor characteristics), the indicators of the administrative systems formation level $\left(R_{s f r}\right)$ and the level of their stability $\left(R_{s t k}\right)$ are chosen to solve the problem.

Thus, the formula for the corresponding correlation-regression model is:

$$
y=b_{0}+b_{1} x_{1}+b_{2} x_{2},
$$

where $y$ is a dependent variable (volume of net income from sales of products, ths. UAH); $\mathrm{x}_{1}, \mathrm{x}_{2}$ are independent variables (the level of administration system formation and the level of its stability); $b_{1}, b_{2}$ are model parameters.

Appropriate calculations for the formed hypothesis check are made in the activities of a number of domestic business entities, in particular, private joint-stock company "KhmelnychchynaAuto" and state enterprise "Novator". The construction of correlation-regression models for these enterprises was carried out using the Analysis Data module of MS Excel. At the same time, the significance of the models is estimated with a reliability of $95 \%$ according to Fisher's criterion. The number of observations in each case was the same -16 periods. According to the calculations, the corresponding regression models were obtained (Table 1).

Table 1

Regression dependence of net income from the parameters of the administration system

\begin{tabular}{|l|l|l|c|c|}
\hline \multicolumn{1}{|c|}{ Enterprises } & \multicolumn{1}{|c|}{ Regression models } & $R^{2}$ & $\begin{array}{c}\text { Estimated value } \\
\text { of Fisher's } \\
\text { F-criterion }\end{array}$ & $\begin{array}{c}\text { Table value } \\
\text { of Fisher's } \\
\text { F-criterion }\end{array}$ \\
\hline "Khmelnychchyna-Auto" & $y=12,4+5,24 x_{1}+6,68 x_{2}$ & 0,86 & 43,41 & 3,81 \\
\hline "Novator" & $y=2,29+2,5 x_{1}+4,16 x_{2}$ & 0,87 & 46,25 & 3,81 \\
\hline
\end{tabular}

Symbols: $y$ is the dependent variable (volume of net income from sales of products, ths. UAH); $x_{1}, x_{2}$ are the level of administration system formation and the level of its stability.

Source: calculated by authors 
Thus, the regression dependences from the parameters of the administration system of domestic enterprises in Table 1 confirm the hypothesis concerning the influence of such systems on the resulting performance indicators of the business entity. Each of the constructed models is adequate and suitable for practical use, which is confirmed by calculations of the coefficient $R^{2}$, the calculated values of Fisher's F-criterion and their comparison with tabular values.

\section{Conclusions and prospects for further research}

Thus, the methodical approaches to the economic evaluation of administration systems in the management of enterprises are considered and it is established that under present conditions most of the projects on construction or improvement of administrative systems belong to the category of investment projects, which, accordingly, are related to investment costs. Consequently, this necessitates the implementation of commonly used in investment management methodical approaches for the economic evaluation of the investments' efficiency in the administration systems.

The main approaches to the economic evaluation of administrative systems in the frameworks of management business processes reengineering are outlined and characterized. They include traditional financial methods, probabilistic methods, qualitative analysis tools, financial, qualitative or combined models, portfolio analysis, budget approach, project approach. Thus, the traditional financial methods of the economic evaluation of the administration systems in the management of enterprises provide for the calculation of the payback period, the net present value, the internal or average rate of return, the profitability index, the level of investments' return, etc. Among the methods and approaches to solving the problem, the estimated Total Cost of Ownership (TCO), IT Scorecard (consideration of customer projections, finance, processes and training and development in the frameworks of administrative processes in the enterprise and administration systems) on enterprise and administration systems), Activity Based Costing $(\mathrm{ABC})$, Cost/Schedule Control Systems Criteria (C/SCSC), Applied Information Economics (AIE),
Total Value of Opportunities (TVO), Total Economic Impact (TEI), Rapid Economic Justification (REJ), etc.

The hypothesis about the influence of administrative systems on the resulting indicators of a business entity was confirmed based on the results of calculations. This problem has been solved using correlation-regression analysis. Net income from sales of products (which is known to be one of the most representative absolute indicators of the economic efficiency of production and economic activity of the enterprise) was selected as the resulting (or dependent) variable. Among the independent variables (factor characteristics), the indicators of the level of administrative systems formation $\left(R_{s f r}\right)$ and the level of their stability $\left(R_{s t k}\right)$ were chosen to solve the problem.

\section{References}

1. Anisiforov, A. B. i Anisiforova, L. O. (2014). Metodiki ocenki effektivnosti informacionnyh sistem $i$ informacionnyh tehnologiy $v$ biznese [Methods for assessing the effectiveness of information systems and information technology in business]. Sankt-Peterburg: Sankt-Peterburgskiy gosudarstvennyj politehnicheskiy universitet. [in Russian].

2. Bekker, M. V. (2010). Metody ocenki ekonomicheskoy effektivnosti innovaciy $v$ sfere informacionnyh system [Methods for assessing the economic efficiency of innovation in the field of information systems]. Vserossiyskiy zhurnal nauchnyh publikaciy, 4, p. 57-58. [in Russian].

3. Gavrilenko, M. A. (2013). Primenenie teorii nechetkih mnozhestv $v$ ocenke riskov investicionnyh proektov [Application of the theory of fuzzy sets in the risk assessment of investment projects]. Audit i finansovyi analiz, 5, p. 75-81. [in Russian].

4. Glushak, N. V. (2008). Metodika ocenki effektivnosti vnedreniya informacionnoy sistemy dlya realizacii zadach kontrollinga [Methods of assessing the effectiveness of the implementation of an information system for the implementation of controlling tasks]. Izvestiya Rossiyskogo gosudarstvennogo pedagogicheskogo universiteta im. A. I. Gercena, 25, p. 83-88. [in Russian].

5. Gontard, P. Ch., Stankevich, L. I., Gerasimova, E. S. $i$ Hlamov, V. V. (2015). Sovokupnaya stoimost' vladeniya - novyi pokazatel' $v$ upravlenii 


\section{O. Kuzmin, V. Ovcharuk, V. Zhezhukha}

laboratoriey [Total Cost of Ownership - a new indicator in laboratory management]. Orgzdrav: novosti, mnenija, obuchenie, 2, p. 87-95. [in Russian].

6. Kaygorodcev, G. I. and Kravchenko, A. V. (2015). Metodika ocenki effektivnosti informacionnyh sistem [Methods for assessing the effectiveness of information systems]. Prikladnaya informatika, 10/1, p. 5-14. [in Russian].

7. Komarova, I. L. (2014). Metody otsinky investytsiinykh proektiv yak skladova uspishnoi diialnosti silskohospodarskykh pidpryiemstv [Methods of evaluation of investment projects as a component of the successful activity of agricultural enterprises]. Formuvannia rynkovykh vidnosyn $v$ Ukraini, 9, s. 60-63. [in Ukrainian].

8. Levkina, N.N. (2009). Sovremennye metody ocenki effektivnosti investiciy $v$ obekty intellektual'noy sobstvennosti [Modern methods of evaluating the effectiveness of investments in intellectual property]. Investicionnaya politika, 12, s. 22-27. [in Russian].

9. Morshcheniuk, T. S. (2009). Pryiniattia ta obhruntuvannia investytsiinykh rishen $v$ umovakh ryzyku [Acceptance and justification of investment decisions under risk conditions]. Ekonomika promyslovosti, 4, s. 109-114. [in Ukrainian].

Skvortsov, I. B. (2003). Efektyvnist investytsiinoho protsesu: metodolohiia, metody $i$ praktyka [Efficiency of the investment process: methodology, methods and practice]. Lviv: Vydavnytstvo Lvivskoi politekhniky. [in Ukrainian]
12. Shemaiev, V. V. ta Romodan, O. O. (2014). Otsinka finansovoi efektyvnosti investytsiinykh proektiv, shcho pidtrymuiutsia mizhnarodnymy finansovymy orhanizatsiiamy [Estimation of financial efficiency of investment projects supported by international financial organizations]. Finansy Ukrainy, 5, p. 96-105. [in Ukrainian].

13. Filippov, V. P. i Shul'djasheva, E. O. (2015). Primenenie metoda ocenki sovokupnogo ekonomicheskogo effekta ot vnedreniya sredy razrabotki [Application of the method of estimating the cumulative economic effect of the development environment]. Vestnik Rossiyskogo universiteta kooperacii, 2, p. 57-62. [in Russian].

14. Yankovyi, O. H., Melnyk, N. V. ta Yankovyi, V. O. (2013). Otsinka investytsiinykh proektiv na pidpryiemstvakh kharchovoi promyslovosti Ukrainy [Estimation of investment projects at enterprises of the food industry of Ukraine]. Ekonomika kharchovoi promyslovosti, 2, s. 49-53. [in Ukrainian].

15. Yastremska, O. M. (2004). Investytsiina diialnist promyslovykh pidpryiemstv: metodolohichni ta metodychni zasady [Investment activity of industrial enterprises: methodological and methodical principles]. Kharkiv: VD “Inzhek”. [in Ukrainian].

16. Zamlynskyi, V. A. (2014). Finansovo-ekonomichni pokaznyky efektyvnosti investytsiinykh protsesiv na

17. pidpryiemstvi [Financial and economic indicators of the efficiency of investment processes at the enterprise]. Ekonomichnyi analiz, 16/2, p. 12-18. [in Ukrainian]. 